\title{
PLL を応用した周波数基準信号の位相雑音低減法の提案
}

\author{
正員 作 田幸 憲 （日本大学） \\ 学生員古川 誠 (日本大学) \\ 正員 関 根 好 文 (日本大学)
}

A Proposal on Reduction Method of Phase Noise based on PLL Systems for Reference Frequency Signal

Sakuta Yukinori, Member, Furukawa Makoto, Student Member, Sekine Yoshifumi, Member (Nihon University)

Measuring the phase noise using a PLL is known as a highly precise method. But the method can't be used when the stability of a test oscillator is higher than the stability of a reference frequency source in the PLL.

So we propose a new method that reduces the phase noise in the reference frequency source. This method adds outputs of $\mathrm{m}$ PLLs locked by the standard oscillator which is the reference frequency source. In this paper, we clarify theoretically that $L(f)$ can be improved by $10 \log m \mathrm{~dB}$ in Fourier frequency range which is higher than the PLL's natural frequency and substantiate this experimentally.

キーワード：基哖周波数源，位相雑音，位相同期回路

\section{1. まえがき}

近年の移動体通信機器の急速な普及や周波数に関する度 量衡学の立場から，周波数基淮源の低位相雑音化に対する 要求が高まっている(1)(2)。

低位相雑音化に関する検討については，従来より，発振 回路を構成する素子の特性に着目したもの (2)(3) や発振の

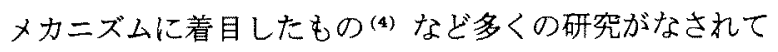
おり，その位相雑音の測定法についても種々検討されてい $ろ^{(5)}$ 。

従来より，高精度な周波数基準信号の位相雑音測定法と して位相同期回路（以下PLLと記す）を用いた方法が知ら れている(6)。しかし,この位相同期法の測定結果には, 被 測定発振器の位相雑音の他, PLL 回路内の基準発振器の位 相雑音も含まれるため, 被測定発振器の安定度が基準発振 器の安定度と同等かそれより悪いものでなければ正確な評 価が出来ないという問題がある。このため, 現在簡易的に は, この被測定発振器と同構成で周波数可変機能を付け加 えた回路構成を用いて，両者の位相雑音の大きさが等しい と仮定して測定する方法が用いられている。しかし，一般 に用いられる可変容量素子はQの高いものが得にくく，そ の結果, 元の発振器よりも安定度が少化することが考えら れ，より高い安定度を持つ位相雑音測定には不十分である と考えられる。従って, 高以安定度を有する被測定発振器
の位相雑音を測定しようとする場合, 測定系の基準発振器 となる PLL 内の電圧制御水晶発振器 (以下VCXO と記す) には極めて低位相雑音のものが望まれる。

そこで, 我々は位相同期法における周波数基準信号とし て, 常に被測定発振器の位相雑音より小さい周波数基準信号 を得ることを目的に，PLLを応用した位相雑音低減法につ いて検討している。先に我々は，PLLにおいてその閉ルー プ伝達関数の関係から VCXO 出力の位相雑音には，PLL の自然周波数 $f_{n}$ より低い放調周波数範囲においては基淮発 振器の位相雑音が移し込まれて現れるが， $f_{n}$ より高い離調 周波数範囲においてはその VCXO 固有の位相雑音が現れ ることを示した(7)。

本論文で提案する手法はこの性質を利用したもので，一 つの基準発振器に同期する $\mathrm{m}$ 個の PLL 出力を加算するこ とにより位相雑音を低減寸る方法である。これは，各 PLL 出力が $f_{n}$ 以下の飾調周波数では位相同期されているため電 圧加算 ${ }^{(8)}$ されるが, $f_{n}$ 以上では各 VCXO 固有の雑音が現 れるため電力加算 (8)にしかならず, 結果として $f_{n}$ 以上の離 調周波数で位相雑音を低減できることが期待できる。

本論文では，提案するシステムの加算器出力の電力スペ クトル密度関数を求めることにより, 位相雑音を評価する 理論式の導出を行い，理論の上から fn 以上の離調周波数に 拈いて $10 \log \mathrm{m} \mathrm{dB}$, 位相雑音を低減可能であることを明 らかにする。また，提案するシステムの構成上，系の構成 
要素による付加雑音の影響が問題しなるため，その付加雑 音の影響について検討䘮行う。次に，系の応答特性の振る 舞いについて，理論との検証を目的に，安定度の測定が容 易な LC 型の電圧制御発振器 (以下VCO と記す) 在用い て実測による検討を行う。また，実際に被測定発振器と同 程度の安定度を持つと考えられる電圧制御水晶発振器を用 いた場合についても実測による検討を行い，本方法が位相 雑音の低減に有効な方法であることを明らかにする。

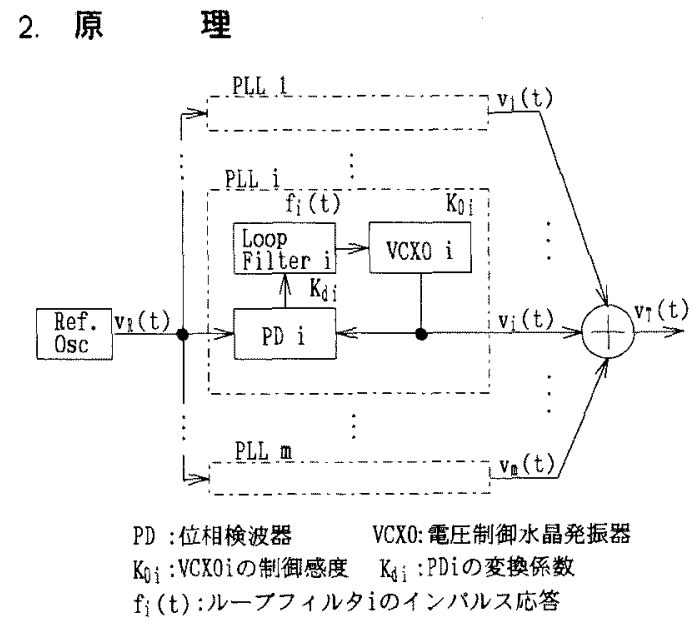

図 1 システムの構成図

Fig. 1. Configuration of system.

図 1 に提案するシステムの構成図を示す。本システムは 1 つの基準発振器, その基準発振器に同期した出力信号を 得るための $\mathrm{m}$ 個の PLL，および各 PLL の VCXO 出力を 加算するための加算器加ら構成されている。また, 各 PLL はそれぞれ位相険波器（以下，PD と記す），Loop Filter， VCXO から構成されている。

以下，理論式導出の流れから本システムの原理を示す。 まず基準発振器出力 $v_{R}(t)$, i 番目の PLL 内の VCXOi 出 力 $v_{i}(t)$ を次式のように表す。

$$
\begin{aligned}
& v_{R}(t)=V_{R} \cdot \cos \left\{\omega_{0} t+\phi_{R}(t)\right\} \cdots \cdots \\
& v_{i}(t)=V_{i} \cdot \sin \left\{\omega_{0} t+\phi_{i}(t)+\phi_{c i}(t)\right\}
\end{aligned}
$$

但 $L, \omega_{0}\left(=2 \pi v_{0}\right):$ 公称角周波数, $V_{j} / \sqrt{2}:$ 公称電压, $\phi_{j}(t)$ : 微小位相雑音, $(\mathrm{j}=\mathrm{R}, \mathrm{i}), \phi_{c i}(t)$ : 被制御位相, $\mid \phi_{i}(t)+$ $\phi_{c i}(t) \mid \ll 1$

位相同期状態において PLLi の閉ループ伝達関数 $H_{i}(f)$ は次式のように表される。

$H_{i}(f) \equiv \frac{\Phi_{c i}(f)}{\Phi_{R}(f)-\Phi_{i}(f)}=\frac{K_{0 i} K_{d i} F_{i}(f)}{j 2 \pi f+K_{0 i} K_{d i} F_{i}(f)} \cdots$

但し, $\Phi_{c i}(f), \Phi_{j}(f), F_{i}(f): \phi_{c i}(t), \phi_{j}(t), f_{i}(t)$ のフーリエ 変換, $(\mathrm{j}=\mathrm{R}, \mathrm{i})$

従って, m個の PLL が全て同期しているときの VCXO のそれぞれの出力を加算して得た，加算器出力 $v_{T}(t)$ は次
式のように求められる。

$$
\begin{aligned}
v_{T}(t) & =\sum_{i=1}^{m} v_{i}(t)=\sum_{i=1}^{m} V_{i} \cdot \sin \left\{\omega_{0} t+\phi_{i}(t)+\phi_{c i}(t)\right\} \\
& \approx m \cdot V \cdot \sin \left\{\omega_{0} t+\phi_{T}(t)\right\} \ldots \ldots \ldots \ldots \ldots
\end{aligned}
$$

但 $\left|\theta_{i}(t)\right| \ll 1,\left|\phi_{T}(t)\right| \ll 1$

以下，簡単のため $V_{1}=V_{2}=\ldots=V_{m} \equiv V$ とすると， $v_{T}(t)$ は次式のように導ける。

$v_{T}(t)=m \cdot V \cdot \sin \left[\omega_{0} t+\frac{1}{m} \sum_{i=1}^{m}\left\{\phi_{i}(t)+\phi_{c i}(t)\right\}\right]$

式 (5)より PLLによりそれぞれ同期したm個の出力を力 算したとき振幅は $\mathrm{m}$ 倍に，位相雑音 $\phi_{i}(t)+\phi_{c i}(t)$ はm個の 雑音の平均となることがわかる。

この $v_{T}(t)$ の片側電力スペクトル密度関数 $S_{v T}^{+}(f)$ は, $v_{T}(t)$ の自己相関関数のフーリエ変換によって導かれる。

今, 各 VCXO の位相雑音の統計的性質が等しい, 即ち $S_{\phi 1}=S_{\phi 2}=\ldots=S_{\phi m} \equiv S_{\phi}$ として, $S_{v T}^{+}(f)$ を求める と, $S_{v T}^{+}(f)$ 注次式のようになる。

$$
\begin{aligned}
S_{v T}^{+}(f) & =\frac{(m V)^{2}}{2} \delta\left(f-\nu_{0}\right) \\
& +\frac{(m V)^{2}}{4}\left\{G_{1}\left(f-\nu_{0}\right) \cdot S_{\phi R}^{\prime}\left(f-\nu_{0}\right)\right. \\
& \left.+\frac{1}{m} G_{2}\left(f-\nu_{0}\right) \cdot S_{\phi}^{\prime}\left(f-\nu_{0}\right)\right\} \cdots \cdots
\end{aligned}
$$

但L, $G_{1}(f)=|H(f)|^{2}, G_{2}(f)=1+|H(f)|^{2}-H(-f)-$ $H(f), \delta(f):$ デルタ関数, $S_{x}^{\prime}(f): \mathrm{x}$ の片側電力スペクト 儿密度関数

一方, 安定度の尺度として, 搬送波からの離調周波数 $\mathrm{f}$ に㧍ける単位周波数当たりの雑音電力と全電力の比として 定義された $L(f)$ が知られている(9)。式 $(6)$ で示される $\mathrm{m}$ 個の VCXO 出力加算して求めた $S_{v T}^{+}(f)$ の $L(f)$ を $L_{T(m)}(f)$ とすると, $L_{T(m)}(f)$ は次式のようになる。

$L_{T(m)}(f) \approx \frac{1}{2} G_{1}(f) \cdot S_{\phi R}^{\prime}(f)+\frac{1}{2 m} G_{2}(f) \cdot S_{\phi}^{\prime}(f)$.

式 (7) より $v_{T}(t) の L_{T(m)}(f)$ は公称周波数の周りに基 淮発振器の位相雑音 $S_{\phi R}^{\prime}$ とVCXO の位相雑音 $S_{\phi}^{\prime}$ がそれぞ れ伝達特性 $G_{1}(f), G_{2}(f)$ の影響によって帯域制限されて現 れ，さらに VCXO 固有の位相雑音が現れる離調周波数範 囲では $1 / \mathrm{m}$ 倍されることがわかる。

そこでまず, $G_{1}(f), G_{2}(f)$ について検討を行う。今,ルー プフィルタとして利得 $G_{A}$ を持つラグリードフィルタを用い た場合，制動定数を $\zeta, P L L の$ 自然角周波数を $\omega_{n}\left(=2 \pi f_{n}\right)$, ループ利得を $K_{v}=K_{0} K_{d} G_{A}$ とすると, $G_{1}(f), G_{2}(f)$ は 次式のように表せる。

$$
\begin{aligned}
& G_{1}(f)=\frac{1+\left(2 \zeta-\omega_{n} / K_{v}\right)^{2}\left(f / f_{n}\right)^{2}}{1+\left(4 \zeta^{2}-2\right)\left(f / f_{n}\right)^{2}+\left(f / f_{n}\right)^{4}} \\
& G_{2}(f)=\frac{\left(\omega_{n} / K_{v}\right)^{2}\left(f / f_{n}\right)^{2}+\left(f / f_{n}\right)^{4}}{1+\left(4 \zeta^{2}-2\right)\left(f / f_{n}\right)^{2}+\left(f / f_{n}\right)^{4}} .
\end{aligned}
$$




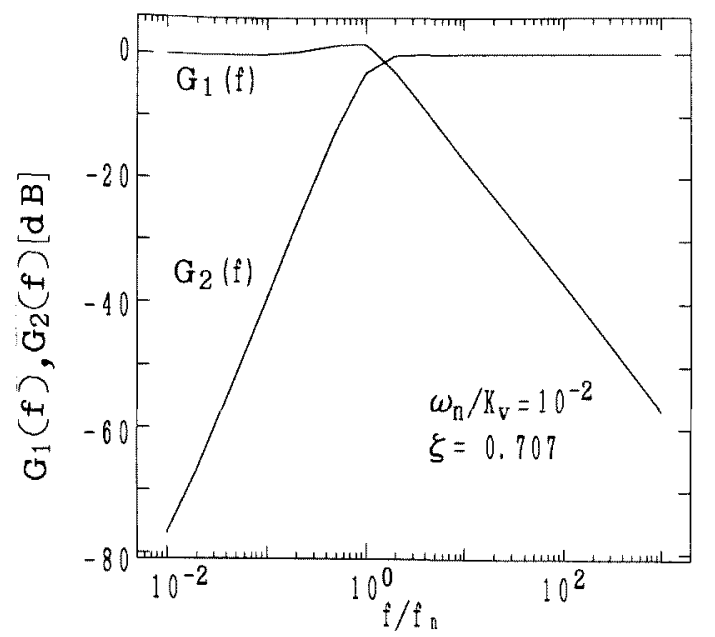

図 $2 f / f_{n}$ に対する $G_{1}(f), G_{2}(f)$

Fig. 2. $G_{1}(f), G_{2}(f)$ vs. $f / f_{n}$.

図 2 に式 (8) をもとに $\omega_{n} / K_{v}=10^{-2}, \zeta=0.707$ とし たときの $G_{1}(f), G_{2}(f)$ の特性の一例を示す。同図より $L_{T(m)}(f)$ は低域通過特性を示す $G_{1}(f)$ により fnまでの 離調周波数範囲では $S_{\phi R}^{\prime}(f)$ の影響がそのまま現れ，高域 通過特性を示す $G_{2}(f)$ により fn より高い離調周波数範囲 では $S_{\phi}^{\prime}(f)$ の影響がそのまま現れることがわかる。

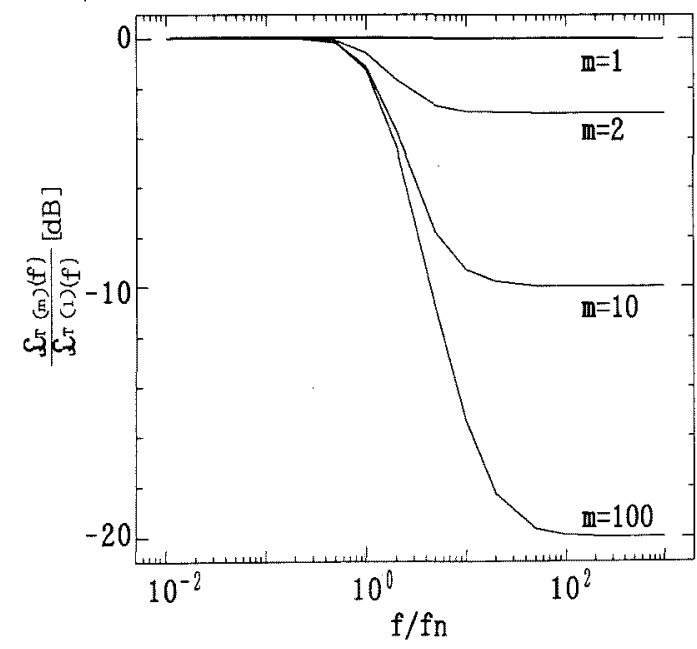

図 3 パラメータmに対寸る $L(f)$ の計算值

Fig. 3. Calculation results of $L(f)$ for parameter m.

次にmについて検討を行う。図 3 に $S_{\phi R}^{\prime}(f)=S_{\phi}^{\prime}(f)$, $\omega_{n} / K_{v}=10^{-2}, \zeta=0.707$ としたときのmをパラメータと して $L_{T(m)}(f)$ を $\mathrm{m}=1$ 個の場合である $L_{T(1)}(f)$ で正規化 したものを示す。同図より fn まではmに関倸なく同じ值で あるのに対して，VCXO 固有の雑音が睍れる fnより高い 周波数になると $1 / \mathrm{m}$ の影響を受けて減少し， $10 \log \mathrm{m} \mathrm{dB}$ だけ小さくなることがわかる。

以上のこしからら 1 つの基準発振器に位相同期したm個の PLL 出力を加算することにより, PLLの自然周波数 fn 以
上において $L(f)$ を $10 \log \mathrm{m} \mathrm{dB}$ 改善可能なことがわかる。 ここで, 基準発振器と VCXO の組み合わせには次の 3 通りが考えられる。

1)VCXO の安定度が基準発振器の安定度よりも悪い場合 $\rightarrow S_{\phi R}^{\prime} \ll S_{\phi}^{\prime}$

2) VCXO の安定度と基準発振器の安定度が同等の場合 $\rightarrow S_{\phi R}^{\prime}=S_{\phi}^{\prime}$

3)VCXO の安定度が基準発振器の安定度よりも良い場合 $\rightarrow S_{\phi R}^{\prime} \gg S_{\phi}^{\prime}$

しかし，3）の場合は，高安定な基準周波数源を得る目的 からあまり現奏的ではない。そこで，ここでは1)，2)の場 合について検討寸る。

まず1) の場合について，この場合の $L_{T(m)}(f)$ は式 (7) そのものとなる。しかし，VCXOの安定度が基準発振器の 安定度よりも悪い場合には，その位相雑音電力レベルの差 $S_{\phi R}^{\prime}(f)-S_{\phi}^{\prime}(f)$ を考慮しなければならない。

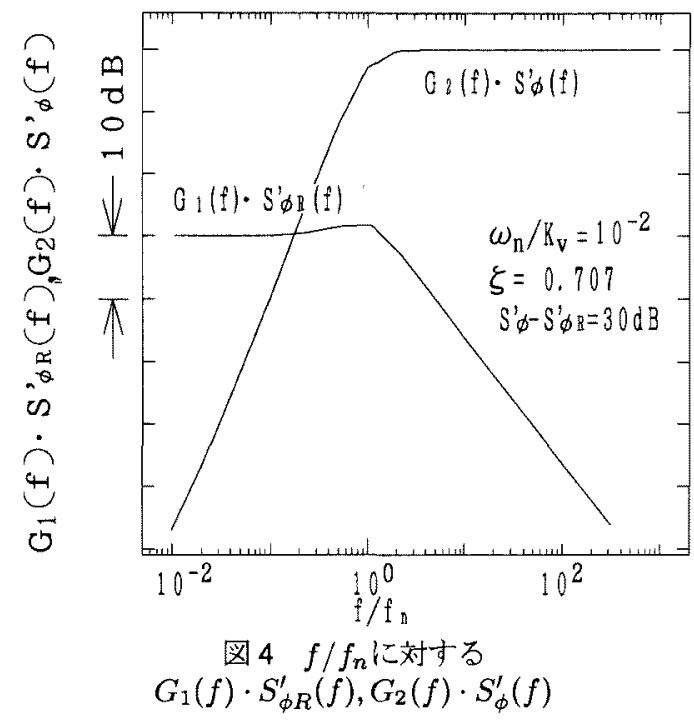

Fig. 4. $G_{1}(f) \cdot S_{\phi R}^{\prime}(f), G_{2}(f) \cdot S_{\phi}^{\prime}(f)$ vs. $f / f_{n}$

図 4 にm=1で $S_{\phi R}^{\prime}(f)$ と $S_{\phi}^{\prime}(f)$ の差を $30 \mathrm{~dB}$ とし,ル プフィルタとて先と同様のラグリードフィルタを用いた 場合の $G_{1}(f) \cdot S_{\phi R}^{\prime}(f), G_{2}(f) \cdot S_{\phi}^{\prime}(f)$ の特性の一例を示す。 同図より $L_{T(m)}(f)$ には, fnより低い周波数まで $G_{2}(f)$ に より $S_{\phi}^{\prime}(f)$ の影響が大きく現れ， $G_{1}(f)$ により $S_{\phi R}^{\prime}(f)$ の 現れる範囲が狭くなることがわかる。

次に2) の場合について, 基準発振器と PLL 内の VCXO の位相雑音電力が同程度で $S_{\phi R}^{\prime}(f)=S_{\phi}^{\prime}(f)$ であるから， この場合, $L_{T(m)}(f)$ は次式となる。

$L_{T(m)}(f)=\frac{1}{2} \cdot\left\{G_{1}(f)+\frac{1}{m} G_{2}(f)\right\} \cdot S_{\phi}^{\prime}(f)$

式 (9)により, $\mathrm{m}=1$ のときの $L_{T(m)}(f)$ には同一レべ ルの雑音 $S_{\phi}^{\prime}(f)$ が $G_{1}(f), G_{2}(f)$ の影響を受けて現れる ため, $G_{1}(f) \cdot S_{\phi R}^{\prime}(f), G_{2}(f) \cdot S_{\phi}^{\prime}(f)$ の特性は, 図 2 に 示す $G_{1}(f), G_{2}(f)$ と同じ形となることがわかる。即ち 


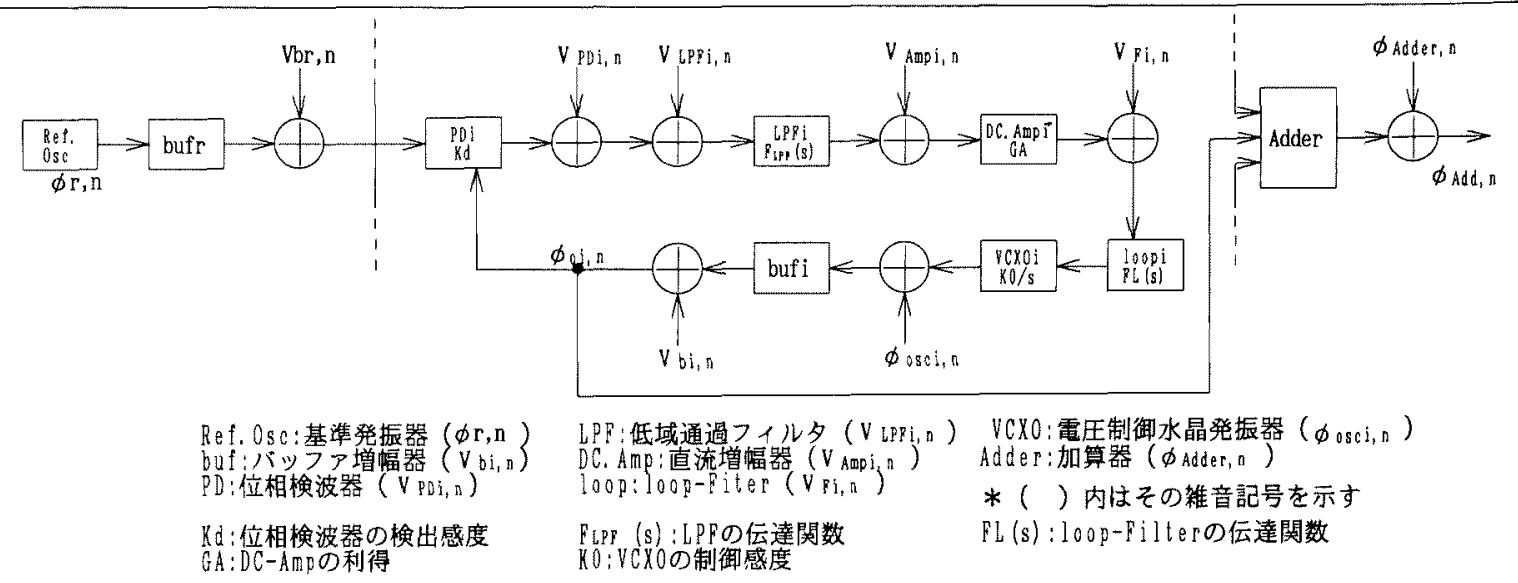

図 5 i 番目のPLLにおける構成要素の付加雑音

Fig. 5. Block diagram of $P L L_{i}$ with additive noise sources.

$L_{T(m)}(f)$ には, fn までの周波数範囲において $G_{1}(f)$ によ り $S_{\phi R}^{\prime}(f)$ の影響が大きく現れ，fn 以上の離調周波数範囲 において $G_{2}(f)$ により $S_{\phi}^{\prime}(f)$ の影響が現れる。

以上のことから $S_{\phi R}^{\prime}(f) \ll S_{\phi}^{\prime}(f)$ の場合, $S_{\phi R}^{\prime}(f)$ と $S_{\phi}^{\prime}(f)$ の位相雑音電力レベルの差に忘じて VCXO 固有の 雑音が現れる䧺調周波数範田が決まり，その範团において $10 \log \mathrm{m} \mathrm{dB}$ 位相雑音は小さくなることがわかる。

\section{3. 付加雑音に関する険討}

図 1 に示すように提案するシステムは複数個のPLL に より構成されるため，その構成要素による付加雑音が問題 になると考えられる。そこでPLL 系に抠る付加雑音の解 析法として挙げられる V.F.KROUPAによる手法(10) を参 考に提案するシステムの付加雑音について検討を行った。

図 5 に付加雑音を考慮した提案するシステムの構成図の 一部を示す。図中甲恮て各構成要素による付加雑音を示 し，図中の記号に拈ける下付き $\{, n\}$ は各構成要素の雑音 であることを示す。

まず $\mathrm{i}$ 番目のPLLについてそれが位相同期状態にある ときの VCXO 出力 $\phi_{o i, n}$ を求めると次式のように表される。

$$
\begin{aligned}
\phi_{o i, n} & =\left[\phi_{r, n}+\frac{V_{P D i, n}+V_{L P F i, n}}{K_{d}}+\frac{V_{A m p i, n}}{K_{d} \cdot F_{L P F}(s)}\right. \\
& \left.+\frac{V_{F i, n}}{K_{d} \cdot F_{L P F}(s) \cdot G_{A}}\right] \cdot H(s) \\
& +\phi_{o s c i, n} \cdot[1-H(s)] \cdots \ldots \ldots \ldots \ldots \ldots \ldots
\end{aligned}
$$

但し, Loop-Filter の帯域はLPF の帯域よりも非常に狭く， バッファ増幅器の雑音は発振器のものより小さいとした。

さらにm個のPLL が全て位相同期状態にあるとし，式 (10) を用いて加算器出力 $\phi_{A d d, n}$ を求めると, 次式のように 導ける。

$$
\phi_{A d d, n}=\sum_{i=1}^{m} \phi_{o i, n}+\phi_{A d d e r, n}
$$

$$
\begin{aligned}
& =\left[m \cdot \phi_{r, n}+\frac{1}{K_{d}} \cdot \sum_{i=1}^{m}\left(V_{P D i, n}+V_{L P F i, n}\right)\right. \\
& +\frac{1}{K_{d} \cdot F_{L P F}(s)} \cdot \sum_{i=1}^{m}\left(V_{A m p i, n}\right) \\
& \left.+\frac{1}{K_{d} \cdot F_{L P F}(s) \cdot G_{A}} \cdot \sum_{i=1}^{m}\left(V_{F i, n}\right)\right] \cdot H(s) \\
& +\left(\sum_{i=1}^{m} \phi_{o s c i, n}\right) \cdot[1-H(s)]+\phi_{\text {Adder }, n} \cdots
\end{aligned}
$$

加算器出力の雑音 を $\mathrm{m}=1$ 個の場合である式 (10) と比 較するため, 式 (11) をmで割ることにより正規化すると次 式のようになる。

$$
\begin{aligned}
\frac{\phi_{\text {Add }, n}}{m} & =\left[\phi_{r, n}+\frac{1}{K_{d}} \cdot \frac{1}{m} \sum_{i=1}^{m}\left(V_{P D i, n}+V_{L P F i, n}\right)\right. \\
& +\frac{1}{K_{d} \cdot F_{L P F}(s)} \cdot \frac{1}{m} \sum_{i=1}^{m}\left(V_{A m p i, n}\right) \\
& \left.+\frac{1}{K_{d} \cdot F_{L P F}(s) \cdot G_{A}} \cdot \frac{1}{m} \sum_{i=1}^{m}\left(V_{F i, n}\right)\right] \cdot H(s) \\
& +\frac{1}{m}\left(\sum_{i=1}^{m} \phi_{o s c i, n}\right) \cdot[1-H(s)] \\
& +\frac{1}{m} \phi_{\text {Adder }, n} \cdots \cdots \ldots \ldots \ldots \ldots \ldots \ldots \ldots
\end{aligned}
$$

式 (10) と式 (12) を比較すると位相同期された基準発振 器の雑音 $\phi_{r, n}$ に対して, 固有の位相雑音が現れる $\phi_{o s c i, n}$ は $\mathrm{m}$ 個の総和平均にしかならず，この結果からも $L(f)$ によ る理論式と同様に $10 \log \mathrm{m} \mathrm{dB}$ 位相雑音が改善できること が確認される。さらに, PD, LPF, DC-Amp, loop-Filter の付加雑音に関しても加算器出力における雑音はm個の総 和平均にしかならず， $\mathrm{m}=1$ 個の場合に対して $10 \log \mathrm{m} \mathrm{dB}$ 低減される。更に，Kdを大くすることによってその影響 を低减可能であることがわかる。また, loop-Filter の雑音 は $G_{A}$ を大きくすることによっても低減可能である。しか 
し, 最終段の加算器の雑音はPLL とは全く独立に付加され るため $K_{d}$ とは無関係であり，加算数舜増やすことによっ $\tau \mathrm{m}=1$ 個の場合に対して相対的に低减可能である。

\section{4. 実測による検証}

$\langle 4$-1〉付加稚音に関する検討 前章の検討加ら, 提案 するするシステムの加算器出力では, バッファ増幅器, PD として用いた二重平衡混合器（以下 DBM と記す），直流 増幅器, 加算器に用いたオペアンプの付加雑音が問題とな ることがわかった。そこでまず実際にシステムを構築する 際の個々の雑音の影響を明らかにするため, 実際に実験に 用いた素子について実測による検討を行った。なおLPFお よび Loop-Filter はパッシブ素子で構成されるため雑音は 小さいものとして無視した。

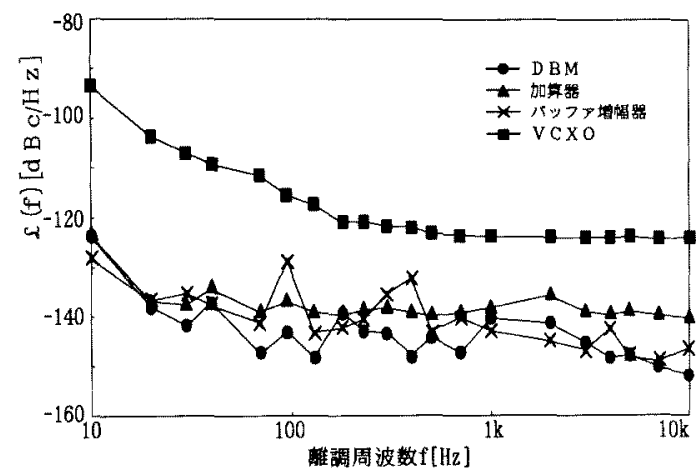

図 6 構成要素の付加雑音の評価

Fig. 6. Evaluation of additive phase-noise.

图6にそれぞれの位相雑音を測定し，その結果を $L(f)$ に 換算したものを示市。同図加次項の検討に扔いて改善す る対象として用いた VCXOの雑音よりも，各構成要素の 雑音の方が $10 \mathrm{~dB}$ 以上小さいため, 加算器出力には個々の 構成要素の雑音の影響は現れないものと考えられる。

〈4・2〉提案するシステムの実測による検討 まず，理 論の検証を目的に，PLL内の VCXOにVCXOよりも雑 音レベルが高く，比較的測定が容易であると考えられる LC 型のVCOを用いて， $S_{\phi R}^{\prime} \ll S_{\phi}^{\prime}$ の場合について実験を行っ た。加算するVCO の個数は $\mathrm{m}=2$ 個とし，奏測における PLLの基準発振器およびVCOには，それぞれ市販のVC$\mathrm{TCXO}(12.8 \mathrm{MHz})$ と, $\mathrm{VCO}(25-50 \mathrm{MHz})$ を用いた。また, PLL の系としては基準発振器である VC-TCXO を 2 派倍 したものにVCO を位相同期させる構成とし，これにより $S_{\phi R}^{\prime} \ll S_{\phi}^{\prime}$ なる条件とした。

提案寸るシステムの各PLL は $f_{n}=500 \mathrm{~Hz}, \omega_{n} / K_{v}=$ $7.1 \times 10^{-5}$, 制動定数 に $S_{\phi R}^{\prime} \ll S_{\phi}^{\prime}$ の場合では $f_{n}$ より低い周波数範囲まで $G_{2}(f)$ によりVCOの影響が大きく現れることが予想される。

図 7 に $=1$ 個の場合と $\mathrm{m}=2$ 個の場合の加算器出力の位 相雑音を測定した結果を示す。 $\mathrm{m}=2$ としたとき，理論式よ りその加算器出力は $\mathrm{m}=1$ 個のときと比べて $10 \log 2=3 \mathrm{~dB}$

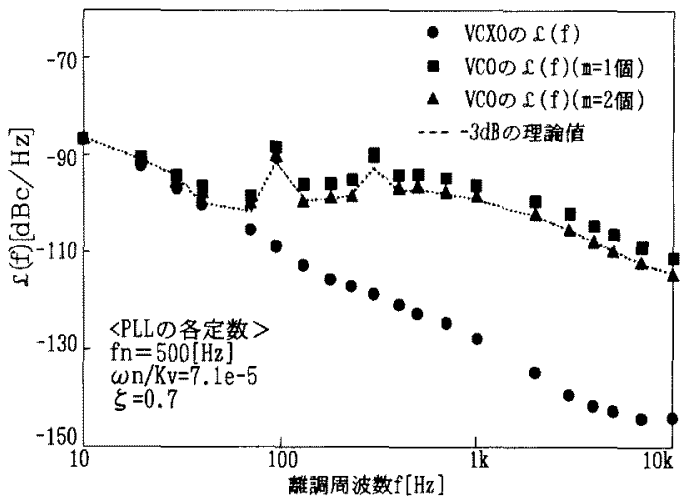

図 7 加算器出力の $L(f)$ (LC 型の VCO の場合)

Fig. 7. Experiment results of $L(f)$ on Adder Output (in the case of VCO).

減少する。理論值として $\mathrm{m}=1$ の測定値を $3 \mathrm{~dB}$ 小さくした 值を点線で示すと，この理論值と $\mathrm{m}=2$ のときの実験值は 良好に一致し, 加算器出力の位相雑音が $\mathrm{m}=1$ 個のときよ りも $\mathrm{m}=2$ 個のときの方が $3 \mathrm{~dB}$ 小さくなっていることがわ かる。

さらに PLL 内の VCXO に基準発振器と同一ロットの VC-TCXO $(12.8 \mathrm{MHz})$ を用いて $S_{\phi R}^{\prime}=S_{\phi}^{\prime}$ の場合について

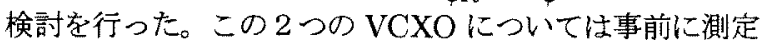
を行い，同程度の位相雑音を持つ事を確認した。また，加 算するVCXOの個数は先と同様に $\mathrm{m}=2$ 個とした。

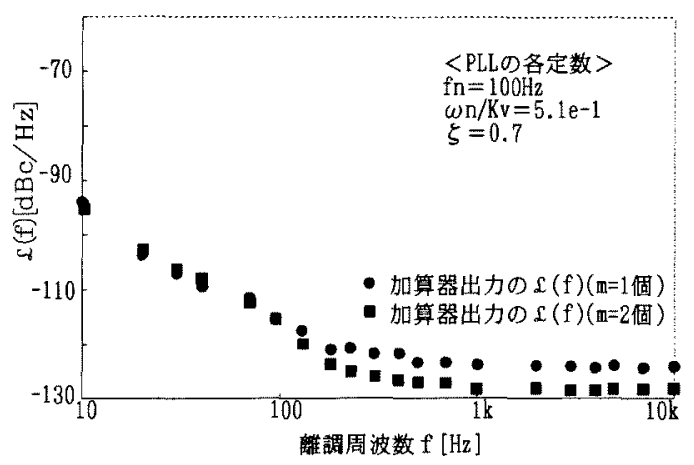

図 8 加算器出力の $L(f)$ (VCXO の場合)

Fig. 8. Experiment results of $L(f)$ onAdder Output(in the case of VCXO).

図 8 にその測定結果を示す。同図より加算器出力の位相 雑音法， $f_{n}$ 以上の離調周波数範囲において，図 7 と同様に $\mathrm{m}=2$ 個のときの方が理論式通り $3 \mathrm{~dB}$ 小さくなっているこ とが確認できた。

\section{5. まとめ}

本論文では一つの基準発振器に同期する $\mathrm{m}$ 個の PLL 出 力を加算することにより $f_{n}$ 以上の離調周波数における位相 雑音を低减する方法を提案した。検討の結果, 位相雑音を $10 \log \mathrm{m} \mathrm{dB}$ 低減可能なことを理論的に明らかにすると共 に，実測による検討を行い，本方法が位相雑音の低減に有 
効な方法であることを害証した。

本手法は，従来より検討されている発振回路そのものを 改善寸る位相雑音低减法とは異なる方法であるため, 従来 の手法によって十分に位相雑音が低减された回路にも独立 して適用可能であり,さらなる位相雑音低减が期待できる。

今後は, PLL の個数を増やして行った場合の独立性や, 雑音検出部に用いられる DBM そのものの雑音, 及び本シ ステムでは改善されなかった $f_{n}$ より低い離調周波数範囲の 位相雑音を低减する手法等について検討を行う予定である。

(平成 10 年 11 月 10 日受付, 同 11 年 2 月 1 日再受付)

\section{文献}

（1）例えば，”マイクロ波発振器における位相雑音の解析・測定・低減 化技術”，電子情報通信学会エレクトロニクスンサイエティ大会, $\mathrm{PC}-1,1997 / 9$.

(2) R.J.Besson: "HIGH PRECISION RESONATORS AND OSCILLATORS", 第 25 回EMシンポジウム,8,pp.49-50,1996/5.

（3）小宮山牧児, 安田嘉之?" 高安定信号源と R F 增幅器のフリッカ位相 雑音”，信学稐,vol.J60-A,no.3,pp.197-204,1977/3.

（4）作田幸憲, 佐々木秀榯, 星野光晴, 関根好文?"水晶発振回路の負荷 $\mathrm{Q}$ に着目した位相雑音の低减に関する一検討”，信学論 (C-II),J77C-II,9,pp.363-370,1994/9.

（5） P. カルタショフ:”時と周波数”，满談社（1980 年）.

(6) 例えば，十文字弘道，太田和夫：“ $L(f)$ 評価における測定系の影 翌”, 電気学会高安定周波数発生回路調査専門委員会, 資料 5-2 (昭 和 51 年)

（7）作田幸㶳，三野秀樹，関根好文：“低位相雑音水晶発振器の位相雑音 測定に関する検討”，信学論 (C-II), vol.J77-C-II,no.1, pp.52$54,1997 / 1$.

（8）平山宏之, 森村正直，小林彬：“雑音処理”，計測自動制御学会 (1988 年).

(9) D.J.Glaze:" Improvements in Atomic Cesium Beam Frequency Standards at the National Bureau of Standards", IEEE. Trans.Instrum. Meas.,vol,IM-19,3,pp.156-160(1970-08).

(10) V.F.KROUPA:"Noise Properties of PLL Systems", IEEE Trans, Comm., vol.COM-30,no.10.pp.2244-2252,1982/10. 正員) 昭和 27 年 2 月 10 日生。昭和 49 年日 本大学理工学部電気工学科卒業。昭和 51 年同大 学大学院理工学研究科電気工学専攻博士前期課程 修了。昭和 55 年同大学大学院理工学研究科電気 工学専攻博士後期課程中退。同年日本大学理工学 部電子工学科助手。以来, 主として水晶発振器の 高安定化, 周波数安定度計測等の研究に従事。現 在, 日本大学短期大学部教授。工学博士。電子情 報通信学会, 映像情報メディア学会各会員。

古川

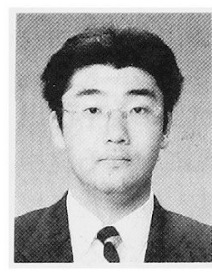

関 根 好 文 (正員) 昭和 19 年 2 月 7 日生。昭和 41 年日本 大学理工学部電気工学科卒業。昭和 43 年同大学 大学院理工学研究科電気工学専攻博士前期課程修 了。同年日本大学理工学部助手。以来, 主として 水晶発振回路及びハードウェアニューロンモデル とその応用に関寸る研究に従事。現在, 日本大学 理工学部教授。工学博士。IEEE, 電子情報通信 学会, 時計学会, 日本神経回路学会各会員。

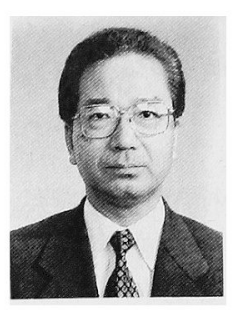

